\title{
External auditor's characteristics, corporate governance and audit reporting quality
}

\author{
Imen Fakhfakh Sakka $^{{ }^{*}}{ }$, Anis Jarboui ${ }^{2}$ \\ ${ }^{1}$ Department of Finance and Accounting, Faculty of Economics and Management of Sfax (FSEGS), Tunisia \\ ${ }^{2}$ Professor of Finance, Department of Finance and Accounting, Higher Institute of Business Administration (ISAAS),Tunisia \\ *Corresponding author E-mail: amouna.fakhfekh@gmail.com
}

\begin{abstract}
The present study is aimed at investigating the combined effect of internal governance mechanisms along with the external auditor reputation on audit reporting quality. This paper is based on a study simple consisting of 28 Tunisian companies listed on the Tunisian Stock Exchange (TSE) over the period 2006-2013. In this respect, and for further consolidating evidence to be provided an empirical study applying multivariate regression panel data, has been undertaken. The results reached have revealed well that timely disclosure is on average some 155 days to be released highly exceeding regulatory ceiling limit, and only $21,43 \%$ of companies have received "modified" audit opinion. Thus, our results have shown the persistence of substitution effects between control effectiveness as implemented by the directors' Board or by the ownership structure in a quest for a brighter external audit reputation, for the sake of ensuring prompt and reliable information.
\end{abstract}

Keywords: Audit Reporting Quality; External Auditor Reputation; Ownership Structure; Directors' Board; Tunisian Companies; Corporate Governance Mechanisms Interaction.

\section{Introduction}

The quality of accounting information, has turned an important issue owing, above all, to the evolutionary modern technological changes and business practices witnessed worldwide (Afify, 2009). A major remarkable factor affecting the quality of information consist in corporate annual reporting punctuality and accuracy, considered a critical factors affecting information usefulness as put at the disposal of external users. In fact, the latter often require a comprehensive, transparent and timely published information likely to help further promote and enhance the decision-making process and reduce the capital market-related information asymmetry in the capital market (Owusu-Ansah and Leventis, 2006), in which financial statements prove to be the exclusively reliable source of information available to the market. So for investor's confidence to be maintained, the audit report has to be published in due course, and to be accurate. It's for these reasons that most of the financial market professional and regulatory organisms have considered to take certain steps in a bid to reduce audit delay and regulate audit opinion. Noteworthy, however, the auditing mission is usually carried out in a multi-stakeholder characterized environment. As a matter of, the auditor shall simultaneously stave to satisfy the audited firm's needs, respect the pertinent laws and regulations, and protect the public as well to ensure a certain proper profitability within a highly competitive market. In this context, several studies have been conducted to highlight the major determinants' source origin of audit reporting. Conducted in various countries' contexts, these studies have revealed the persistence of certain divergences with respect to measures, methodology, applied variables, as well as reached conclusions.
Actually, our research is intended to provide a further to the audit-related literature through an analysis of the association between corporate governance, external auditor's characteristics and audit reporting quality, defined, both, as being time span comprised between the fiscal year-end and audit report publication date thus the likelihood to receive "modified" audit opinion. To this end, certain internal governance mechanisms' characteristics (board directors' and ownership structure) have been incorporated, considered to have an influential due to audit reporting quality. Indeed, corporate governance is maintained through diverse structures and mechanisms likely to help reconcile the executives and shareholders' divergent interests as well as a firm value (Wirtz, 2004), ensure a better performance or output limit wealth transfer among shareholders and the manager thus reducing shareholders risk of being dispossessed. Hence, the more effective these mechanisms prove to be in achieving their monitoring and cooperation role with the external auditor, the higher the audit mission quality will be.

Given, the external audit increasing importance as means were be the leader's possible accounting manipulations can be restricted, conflicts regulated the information asymmetry further reduced between the leader and agent, its intervention as an effective and independent control mechanism seems versatile for ensuring and maintaining the relevance of the produced information.

It, therefore, seems well appropriate to understand the possible interaction between the effectiveness of control as provided by certain governance structures, and the requirement for a distinct audit quality, above all notably its reputations.

Thus, this research is designed to addresses the corporate governance internal mechanisms impact, on the Tunisian listed companies, on audit reporting quality along with the external audit 
reputation and internal governance mechanisms interaction effect on audit reporting quality.

This present articles focus on three major parts. On a first stage, literature review discussion is dealt with along with the research formulation hypotheses. On a second stage, the research is laid highlighting the research methodology while the ultimate section treats the achieved result's analysis, the major concluding remarks and paves the way for potential research horizons.

\section{Literature review and research hypotheses}

\subsection{Audit reporting regulatory framework in Tunisia}

It's worth noting in paragraph 36 of Standard 15 pertaining to the Tunisian Chartered Accountant's Order stipulates that: "The report has to be fixed to enable the reader to be aware of the dates up which the events' posteriori to the financial statements set-up of which auditor is well, have been accounted. For this date, corresponds notably to the review definitive achievement". Once audit check is completed, the external auditor informs the director's board about this investigation results within the month following delivery of financial statements.

According to the article $269 \mathrm{CCC}$, external auditor must expressly indicate in their reports that they conduct an audit in accordance with auditing standards, they approve expressly or certify with reservation, or they disapprove. Shall be null, while auditor report that does not contain an explicit opinion or whose reserves are presented ambiguously or incompletely.

These results must be communicated to shareholders and to company associates via registered mail with acknowledgment of receipt, or via any other means with written record, ahead of the Annual General Meeting (AGM) assembly schedule held for the purpose of approving of financial statement. This meeting must be held within six months following the financial year closure. In such a case, companies lunching public offerings must publish the audit report in the Financial Market Council (FMC) official newsletter as well as in Tunis published daily newspaper within four months following the financial year-end.

\subsection{External auditor reputation}

The external auditor reputation stands as a signal token of quality and helps provide a rather costly service for an identical content In this regard, the relevant elaborated studies have undertaken to distinguish the auditor's quality on the basis of membership pertinence to "Big N" firms. The lather might well prove to be rather highly effective in accomplishing audit services.

As a matter of fact, international auditing firms exhibit a rather strong incentive to achieve the audit tasks on time for the sake of maintaining a high reputation safeguarding, a high-quality brand name or image and increasing their market share. This idea has been tested and validated by the entirety of the previously elaborated research works highlighting that Big $\mathrm{N}$ audit firms are more reliable and far highly qualified to minimize timeliness(Ahmed and Hossain, 2010; Afify, 2009; Owusu-Ansah and Leventis 2006; Mohamed-Nor et al 2010; Modugu and al 2012; Lee and Jahng, 2008; Piot, 2008).

In this context, previous research has shown that the BIG $\mathrm{N}$ firms are more likely to issue "modified" audit opinions than non-Big N (Abdelaziz and Moalla, 2010; Shafie and al, 2009; Li and Wong, 2008; Francis and Yu, 2009; Ruiz-Barbadillo and all, 2004). In effect, a big $\mathrm{N}$ firm effectiveness in publishing audit reports might well have its explanation in its employing highly-qualified specialized personnel (Leventis and al, 2005) as it enjoys more resources and adequate means to set up organized training Besides, it can also be justified by the use of sophisticated hi-tech control devices and significant material resources (Elfouzi and Zarai, 2008) likely to help facilitate effective monitoring, detect errors and accounting irregularities (Farber, 2005).

\subsection{The internal governance mechanisms' effect on audit reporting quality}

As part of this research, a special focus is laid on the major governance mechanisms likely to have an impact on audit reporting quality. They actually consist in two mechanisms namely the director's board and ownership structure.

\subsubsection{The director's board}

This board constitutes a crucial of corporate governance element still its effectiveness as a control mechanism is not very often guaranteed as it highly depends on the following main characteristics.

\subsubsection{Presence of an audit committee}

The presence of an audit committee may well render the control environment effectively reliable once it helps and coordinate the internal and external audit activities with the aim of maintaining an efficient allocation of resources.

In this regard Afify (2009), Vuko and Cular (2014) have highlighted the persistence of a negatively significant relationship between the existence of an audit committee, and the audit report lag. They have pointed out that the audit committee plays a vital role in maintaining communication between management and the external auditor, which would likely affect the audit risk evaluation process, as well the assessment of control; forecast audit checks hours. Validation tests level along with ensuring highly accurate financial information.

The effectiveness of the audit committee is determined by independence, the procedures and the financial expertise of its members. Their results showed that firms how have an effective audit committee, are less likely to issue "modified" audit opinion (Chang and al, 2013).

Yet, the existence of an Audit Committee along with appealing to a reputable external audit represent two critically important factors for effective corporate governance to take place. As nothing is, a priori, known about their interactions' effect trend on audit reporting quality, one might well put forward the following two hypotheses:

H1a: Audit committee negatively affects audit reporting quality. $\mathrm{H} 1 \mathrm{~b}$ : The effect of demand for highly reputable external audit on audit reporting quality varies in presence of an audit committee.

\subsubsection{Board size}

Size stands as is an important factor for a smooth functioning of the director's Board (Mkadmi and Halioui, 2013). Indeed, small size boards can undoubtedly its supervisory role consisting mainly in financial statements, given the fact that endures much fewer bureaucratic problems in addition to the fact of being more functional and liable to provide rather effective financial information quality (Xie et al. 2003).

Noteworthy, however, a large board can assist with providing a greater deal of submitting greater deal of control, submitting greater critical resources, help greatly in avoiding uncertainties and securing a promotional ground for enhancing skills and competences (Singh and al, 2004). In this context, Ezat and El-Masry (2008) have indicated that listed Egyptian companies, involving a large number of directors within the board prove to be more updated with respect to websites.

Still, Farinha and Viana (2006), studying the relationship between the characteristics of the board and the likelihood that the auditor issue an "modified" audit opinion in the Portuguese context, found that the board size has no significant effect on audit opinion. Thus, the following hypotheses sound worth reformulating:

H2a: Board size negatively affects audit reporting quality

$\mathrm{H} 2 \mathrm{~b}$ : The effect of demand for a highly reputable external auditor on audit reporting quality varies in respect of board size. 


\subsubsection{Outside director's proportion within the board}

The external or non-executive directors do not generally have any personal interest in the company. Stand as they are effective factors in monitoring the quality financial information quality and are negatively associated with earning management practice should they represent more than $50 \%$ (Johari et al. (2008). The external members' integration within the board helps well increase the board's the effectiveness of the Board in the management and monitoring activities' effectiveness in order to preventing financial statement's related frauds.

To note, the previous by elaborated research studies dealing with the relationship between the Board outside directors and timeliness process discovered to be contradictory. Some researchers have been led to demonstrate that the proportion of outside director's proportion within the board constitutes an effective fraud-reducing factor (Chen and al; 2006) allowing external auditors to reduce working hours, lessening the testing procedure and reduce a timely span (Azubike and Aggreh, 2014; Afify, 2009; Abdelsalam and Street, 2007) and decrease likelihood to receive "modified" audit opinion (Baygi and all, 2012). Nevertheless, Apadore and Mohd-Noor (2013) have underlined that the more independent the board is the more problematic incentive it tends to be owing to the diversity of opinions that might well be brought about the auditing procedures and likely to impact further extend the audit span. This confirms by well the idea stipulating that the board independence does, by no means, not promote corporate transparency (Haniffa and Cooke, 2002 Wan-Hussin, 2009) nor does it entail any financial adjustments (Abdullah and al, 2010). Consequently, the below may well be posed:

H3a: Outside director's proportion within the board negatively affects audit reporting quality.

$\mathrm{H} 3 \mathrm{~b}$ : The effect of demand for highly reputable external auditor reporting quality varies with respect to outside directors' proportion within the board.

\subsubsection{CEO duality}

Combining both Chairmen and the CEO functions designates well the combination of two roles resulting in a high concentration of power likely to jeopardize the board's independence with a negative impact being engendered on shareholder's wealth. A matter of fact, a structural unit helps well prevent an effective disclosure of information (Gul and Leung, 2004; Haniffa and Cooke, 2002), from taking place, thus standing as a quality control endangering threat, a means of restraining unfavorable information to outsiders' and a factor an increase of timeliness (Afify, 2009) and the likelihood to receive "modified" audit opinion (Baygi and all, 2012).It is in this respect that the agency theory suggests that duality constitutes a major reason for the board's inefficiency (Jensen, 1993), requesting the appeal to hiring a reputable external audit in a bid to broadcast high-quality information. At this junction, the following hypothesis seems well imposed:

H4a: CEO duality negatively affects audit reporting quality

$\mathrm{H} 4 \mathrm{~b}$ : The effect of demand for highly reputable external auditor on audit reporting quality varies with CEO duality.

\subsubsection{Ownership structure}

Another control mode has been put forward by the agency theory, particularly, shareholding whose concentration and composition could strongly influence the power authority relationship between shareholders and managers and would well the shareholders' incentives to invest in firm management control.

\subsubsection{Ownership concentration}

Worth highlighting, the Tunisian companies' capital is most often concentrated in the hands of a minority of owners who prefer to personally control their organisms and dominate the General Shareholders Assembly decisions (presence of control blocks).

In case ownership appears to be widely dispersed, shareholders' direct control becomes rather costly, leading to a greater confidence being devoted to the audit profession as a managerial behavior control means (Ayadi, 2013).

Inversely, however, when the property proves to be concentrated, a greater pressure is being placed on external auditors to achieve elaborating the report within a very short time lapse, for obtaining timely information. This finding is confirmed by the results reached by Al-Ajmi (2008) showing that the more concentrated ownership structure is the shorter audit delay will be. In this context two major studies elaborated by Ezat and El-Masry (2008), as well as, Marston and Polei (2004) have stressed that the dispersed of the company ownership structure helps entice companies to disclose information and have more updated websites to reduce owners' information cost and help them monitor their manager's behavior. Thus, the following hypothesis seems worth testing:

H5a: Ownership concentration negatively affects audit reporting quality

H5b: the effect of demand for highly reputable external audit on audit reporting quality varies with respect to ownership concentration

\subsubsection{Institutional ownership}

Given the considerable weight that have institutional investors enjoy within the company, they are liable to play an active role in monitoring and disciplining of manager discretionary powers as well as financial "reporting" process (Zureigat, 2011), this which might well help minimize financial statement related fraud (Sharma, 2004 et Lajmi et Gana 2011).Previously conducted researches dealing with the relationship between institutional ownership and audit reporting quality are not numerous. Indeed, Al-Ajmi(2008) along with Abdelsalam and Street (2007) have stated that the increased institutional investors' ownership right help well in minimizing the audit achievement allocated time and reduce the likelihood of fraud (Sharma, 2004; Lajmi and Gana, 2011).This leads up to advance the following hypotheses:

H6a: Institutional ownership negatively affects audit reporting quality

H6b: The effect of demand for a highly reputable external audit on audit reporting quality varies according to institutional ownership.

\section{Research sample and methodology}

This section is devoted to discuss the empirical methodology applied for testing the already-developed hypotheses.

\subsection{Sample selection and data}

The applied study sample covers Tunisian companies listed in Tunis Stock Exchange (TSE) over in eight year period from the year 2006 to 2013. Actually, the choice during this period is justified by the fact that the year 2006 was the first year to witness promulgation of the 2005 law on strengthening financial security in Tunisia. All corporate annual reports have been downloaded and manually collected from the Tunis Stock Exchange (TSE) and Financial Market Council (FMC) websites.

To note, Finance-related companies (such as banks, insurances, holding and leasing companies) have been excluded from the initial sample owing to their particular distinctive accounting features as well as their specific requirements, rules and regulations with respect to accounting financial reporting. Besides, companies with missing data as well as a newly TSE introduced ones have been eliminated hence; our ultimate sample turns out to involve some 28 companies ensure achieving 224 observations. It is worth noting that we have considered opting for the balanced panel approach to ensure achieving consistent results. 


\subsection{Variables' measurement and modeling specification}

Audit reporting quality is measured using, both, the timely disclosure and audit accuracy.

To note, the previously conducted studies have undertaken to apply timely disclosure as the calendar day starting from the fiscal year-end up until to audit report publication date .Our proxy for audit accuracy is the audit opinion. For our set research objective to be reached, the following regressions are going to be estimated:

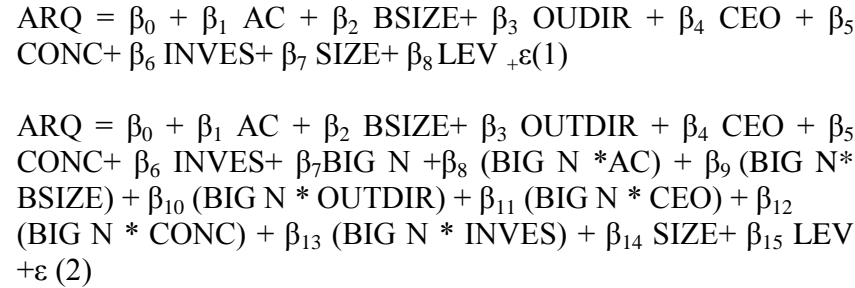

Along with:

$\mathrm{ARQ}=$ audit reporting quality, $\mathrm{AC}=$ audit committee, $\mathrm{BSIZE}=$ the board size, OUTDIR = outside director's within the board, $\mathrm{CEO}=$ CEO duality, $\mathrm{CONC}=$ ownership concentration, INVES= institutional ownership, BIG $\mathrm{N}=$ external auditor reputation, SIZE $=$ firm size, $L E V=$ leverage, $\beta_{0}=$ constant, $\beta_{1} ; \beta_{2} ; \beta_{3} ; \beta_{4} ; \beta_{5}$; $\beta_{6} ; \beta_{7} ; \beta_{8} ; \beta_{9} ; \beta_{10} ; \beta_{11} ; \beta_{12} ; \beta_{13} ; \beta_{14} ; \beta_{15}=$ parameters to be estimated, $\varepsilon=$ models residue

The first regression serves to determine the impact of internal governance mechanisms impact on audit reporting quality. On introducing the variable "external audit reputation", the second regression would serve to test this variable interaction effect with the various internal governance mechanisms on audit reporting quality. Table 1, below, depicts the entirety of the variables' pertaining measurements.

Table 1: Variables Operationalization Summary

\begin{tabular}{|c|c|c|}
\hline Variable names & Symbol & Measures \\
\hline \multicolumn{3}{|l|}{ Dependent variable } \\
\hline \multicolumn{3}{|c|}{ Audit reporting quality (ARQ): } \\
\hline Timely disclosure & TPERIOD & Number of days between the fiscal year-end and the publication date (log) \\
\hline Audit accuracy & $\mathrm{AO}$ & A binary variable taking value " 1 " if auditor issued modified audit opinion," 0 " otherwise \\
\hline \multicolumn{3}{|l|}{ Independent variables } \\
\hline Audit Committee & $\mathrm{AC}$ & A binary variable taking value " $1 "$ if audit committee does exist within company,"0" otherwise \\
\hline Board size & BSIZE & Number of directors within the board \\
\hline Outside directors & OUTDIR & Number of outside directors to total of directors within the board \\
\hline Ownership Concentration & $\mathrm{CONC}$ & $\begin{array}{l}\text { A binary variable taking value " } 1 \text { " if the proportions of shares held by the majority shareholder of } \\
\text { the company }>20 \% \text {, " } 0 \text { " otherwise }\end{array}$ \\
\hline Institutional Ownership & INVES & Proportions of equity held by institutional investors \\
\hline External auditor reputation & BIG N & A binary variable taking value " 1 " if the auditor is a big $\mathrm{N}$ firm , "0" otherwise \\
\hline \multicolumn{3}{|l|}{ Controls variable } \\
\hline Firm size & SIZE & Log of firm's sales \\
\hline Leverage & LEV & Total Liabilities to total Assets \\
\hline
\end{tabular}

\section{Results}

The reached results are presented according three stages. The first two steps depict the descriptive statistics and correlation results relevant summary respectively describing the dependent and independents variables. On a third stage, the results emanating from two step timeliness multiple regressions of audit delay on independent variables are presented.

\subsection{Descriptive statistics}

Table 2 bellow reports the descriptive statistics relevant to the continuous variables subject of study. The table illustrates the descriptive statistics concerning of a minimum, maximum, mean and standard deviation.

Regarding the dependent variable, the analysis indicates that timeliness is of the average rate of 155 day after closure of the fiscal year, ranging between 70 and 333 days. Actually, this value highly exceeds greatly the regulatory ceiling (four months).

These finding suggest that the majority of Tunisian companies do no appear to respect the legal deadlines, despite the Tunisian legislator's efforts in this regard and adoption of the Financial Security Law (2005).

Table 2: Continuous Variables' Descriptive Statistics

\begin{tabular}{|c|c|c|c|c|}
\hline Variables & Min & Max & Mean & Std. Deviation \\
\hline TPERIOD & 70 & 333 & 154,54 & 40,179 \\
\hline BSIZE & 4 & 12 & 8,47 & 1,88 \\
\hline OUTDIR (\%) & 0 & 83 & 41,23 & 26,52 \\
\hline INVES (\%) & 0 & 88,8 & 15,56 & 22,69 \\
\hline SIZE & 13,7 & 20,12 & 17,39 & 1,31 \\
\hline LEV & 8 & 97 & 47,43 & 19,98 \\
\hline
\end{tabular}

Table 3, that follow, reports the Dummy Variable's Descriptive Statistics as Investigated in this Study. It indicates well that most Tunisian companies do not appear to designate an audit committee (92, 86\%), with $62,05 \%$ among them being audited by
No-BIGN firms, $63,39 \%$ tend to be characterized with a president and the CEO respective roles. It is actually this combination of roles which leads to a high concentration of power likely to threaten the board's independence. 
Table 3: Dummy Variables' Descriptive Statistics

\begin{tabular}{|c|c|c|}
\hline Variables & Variable $=0$ & Variable $=1$ \\
\hline $\mathrm{AO}$ & $176(8.57 \%)$ & $48(21.43 \%)$ \\
\hline $\mathrm{AC}$ & $208(92,86 \%)$ & $16(7,14 \%)$ \\
\hline $\mathrm{CEO}$ & $82(36.61 \%)$ & $142(63.39 \%)$ \\
\hline BIG N & $139(62.05 \%)$ & $85(37.95 \%)$ \\
\hline \multicolumn{3}{|c|}{ 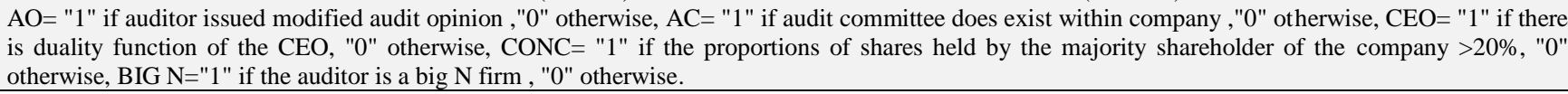 } \\
\hline
\end{tabular}

\subsection{Correlation analysis}

It's worth maintaining that the multicollinearity problem takes place when certain variables are highly or perfectly jointly correlated engendering instability of the estimated coefficients and a strong increase in their standard deviations. The Pearson correlation matrix, presented in (Table 4),bellow, demonstrates well that no correlation appears to be superior to " 0.9 ", thus corroborating the reference work conducted by Tabachnik and Fiddell (2007) such a finding allows to accept the null hypothesis of no correlation between variables.

Table 4: Pearson Correlation Coefficients

\begin{tabular}{|c|c|c|c|c|c|c|c|c|}
\hline 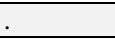 & $\mathrm{AC}$ & BSIZE & OUTDIR & CEO & CONC & INVES & SIZE & LEV \\
\hline $\mathrm{AC}$ & 1 & & & & & & & \\
\hline BSIZE & 0.0138 & 1 & & & & & & \\
\hline OUTDIR & -0.0452 & $0.1432 *$ & 1 & & & & & \\
\hline CONC & -0.0772 & -0.1289 & $0.2198 *$ & -0.0400 & 1 & & & \\
\hline INVES & -0.0260 & 0.0004 & 0.1089 & $-0.1339^{*}$ & $0.2409^{*}$ & 1 & & \\
\hline SIZE & -0.0746 & $0.4378 *$ & 0.0645 & $-0.1751^{*}$ & $-0.1548 *$ & $0.2182 *$ & 1 & \\
\hline LEV & -0.1041 & 0.0879 & 0.0147 & 0.1278 & -0.0706 & -0.0528 & $0.1646 *$ & 1 \\
\hline
\end{tabular}

* Correlation is significant at the 0,05 level (2-tailed)

$\mathrm{AC}=$ "1" if audit committee does exist within company ," $0 "$ otherwise, BSIZE = Number of directors within the board, OUTDIR= Number of outside directors to total of directors within the board, $\mathrm{CEO}=$ " 1 " if there is duality function of the CEO, "0" otherwise, CONC= "1" if the proportions of shares held by the majority shareholder of the company $>20 \%$, "0" otherwise, INVES= Proportions of equity held by institutional investors, SIZE $=$ Log of firm's sales; LEV =Total liabilities to total assets.

\subsection{Multivariate analysis}

For an effective selection of the appropriate of regression method, certain tests seem well applicable to testifying the model's estimation via generalized least squares (GLS) and logistic regression, Panel data approach, by means of STATA 12 software.

Table 5: Multivariate Regression Analysis of the Internal Governance Mechanisms Effect on Audit Reporting Quality

\begin{tabular}{lll}
\hline Variables & $\begin{array}{l}\text { Timely } \\
\text { disclosure } \\
\text { (TPERIOD) }\end{array}$ & $\begin{array}{l}\text { Audit Accuracy } \\
(\mathrm{AO})\end{array}$ \\
\hline AC & -0.057 & -0.068 \\
BSIZE & $-0.031^{* * *}$ & $-0.047^{* * *}$ \\
OUTDIR & -0.060 & 0.095 \\
CEO & $0.150^{* * *}$ & $0.103^{* *}$ \\
CONC & $0.060^{* *}$ & 0.278 \\
INVES & $-0.123^{* * *}$ & $-0.185^{* * *}$ \\
SIZE & $-0.046^{* * *}$ & 0.016 \\
LEV & $0.219^{* * *}$ & $0.135^{* *}$ \\
& & \\
& $\mathrm{~N}=224$ & $\mathrm{~N}=224$ \\
& $\mathrm{R}^{2}=0.4307$ & Pseudo $\mathrm{R}^{2}=0.2246$ \\
& Adjusted $\mathrm{R}^{2}=0.4096$ & Log likelihood $=-90.241$ \\
& Prob $>\mathrm{F}=0.0000$ & Prob $>$ Chi-2 $=0.0000$
\end{tabular}

$*$, **and *** Correlations significant at the $10 \%, 5 \%$ and $1 \%$ level. TPERIOD $=$ Number of days between the financial year-end and the publication date $(\log ), \mathrm{AO}=$ " 1 " if auditor issued modified audit opinion ," otherwise, $\mathrm{AC}=$ " 1 " if audit committee does exist within company ,"0" otherwise, BSIZE = Number of directors within the board, OUTDIR= Number of outside directors to total of directors within the board, CEO= " 1 " if there is duality function of the CEO, "0" otherwise, CONC= "1" if the proportions of shares held by the majority shareholder of the company $>20 \%$, "0" otherwise, INVES= Proportions of equity held by institutional investors, SIZE = Log of firm's sales; LEV =Total liabilities to total assets.

Figuring on table 5, the multiple regression results indicate well that the internal governance mechanisms are discovered to have a remarkable effect on audit reporting quality. Indeed, the two respective exhibit the figures of models $43.07 \%$ and $22.46 \%$ which are actually highly significant within a $1 \%$ threshold this finding leads us to us to reject the null coefficients' hypothesis, thus underlining the model's appropriate fitness. In fact, fact, the attained results prove to reveal well the fact that the very existence of an Audit Committee (AC) turns out to have no noticeable effect on the entirety of the two audit-reporting quality measures, as used in this research. Actually, such a result might well have its explanation in the Tunisian companies' special structure, which seem to be still unaware of the importance of installing a special Audit Committee despite the obligation imposed by the 2005 Financial Security Law, which has made it mandatory for certain companies to set up a special permanent audit committee its prerogatives on monitoring the external auditor's works. In effect, this law has helped identify three major stages through which the audit committee could intervene namely the pre-audit process stage (that of choosing the auditor), the while-stage processing (evaluating the auditor provided service quality) and the post process stage (ensuring, mainly, the implementation of the auditor underlined recommendations).

Furthermore, the Board size (BSIZE) sounds to exhibit a negative and significant effect (at $1 \%$ threshold) on audit reporting quality as measured by TPERIOD and AO. These results suggest well that a large board helps well implement greater more control, eliminate environment uncertainties and facilitate the external auditor's mission. This result proves to be highly consistent with that released by Ezzat Al-Masry (2008). Regarding the outside director's proportion within the board (OUTDIR), the reached results are discovered to be conclusive. Indeed, the relationship is discovered to be non-significant with TPERIOD and AO.

Still, a positive and significant relationship (at $1 \%$ and $5 \%$ ) appears to prevail within the president's combined roles of president's board Chairman and CEO and audit reporting quality. This finding helps confirm the idea that a role dominant personality is likely to render the taken decisions somewhat objective, which is likely to threaten to the external auditor's mission, enticing the auditor to devote a greater deal of time to reviewing the audit accounts and increasing the chances that the firm will be issued a modified opinion. In fact, fact, this result 
proves to be harmoniously consistent with that present by Baygi and al (2012).

With respect to Table 5, and in conformity with the finding discovering by Chen and all (2006) no significant influence appears to persist between the ownership structure and persistence of fraud. However, this relationship proves to change with timely disclosure. Indeed, ownership concentration (CONC) tends to exhibit a simultaneously positive and significant relationship, $1 \%$ level with the total period. This fact confirms the idea that concentrated ownership might well lead the external auditors to further intensify the check and assessment tests extended and extend the audit period deadline, an idea that seems highly consistent with that advanced by Apadore and Mohd-Noor (2013). However, institutional ownership (INVES) revel a negative and significant relationship with TPERIOD and AO at threshold of $1 \%$. Indeed, whenever institutional investors prove to own significant proportion of shares, they were apt to become active investors in firm management control and in monitoring the financial "reporting" process thus facilitating speeding up the accounts of the certification task (Abdelsamen and Street, 2007) .Regarding control variables, the results indicate the prevalence of a significantly negative relationship with timely disclosure (Wan Hussin and Hamahros, 2013; Paurali and all, 2013; Habib and Bhuiyan, 2011).As As for for the second control variable, a positive relationship has been attained between debt (LEV) and ARQ, highlighting that the audit report delivery deadline of the mostly indebted companies discovered to be higher than that of the least indebted ones. This result proves to collaborate well with finding achieved by Cohen and Leventis (2013), Al-Ghanem and Hegazy (2011), Conover and all (2007) and Che-Ahmad and Abdin (2008). Thus, a notable interpretation may be derived from Table 5 namely the impact of changing the dependent variable measurement on reached results. In fact, both TPERIOD and AO measure's respective results turn out to be too statistically significant for relationships with audit reporting quality. In fact, both the effect (AC) and (OUTDIR) remain unchanged showing that none of the coefficients appears to be statistically significant.

Table 6: Multivariate Regression Analysis for the Interaction between External Auditor Characteristics, Corporate Governance and Audit Reporting Quality

\begin{tabular}{lll}
\hline Variables & $\begin{array}{l}\text { Timely disclosure } \\
\text { (T PERIOD) }\end{array}$ & $\begin{array}{l}\text { Audit accuracy } \\
(\mathrm{AO})\end{array}$ \\
\hline AC & $-0.163^{*}$ & 0.755 \\
BSIZE & $-0.015^{*}$ & 0.034 \\
OUTDIR & -0.012 & -0.483 \\
CEO & $0.165^{* * *}$ & $-2.747 * * *$ \\
CONC & $-0.065^{* *}$ & 2.229 \\
INVES & -0.051 & -1.595 \\
BIGN & $0.284^{* * *}$ & $1.511 * *$ \\
BIGN*AC & 0.143 & 0.297 \\
BIGN*BSIZE & $-0.022^{*}$ & -1.075 \\
BIGN* OUTDIR & -0.019 & 7.107 \\
BIGN*CEO & -0.080 & 0.368 \\
BIGN*CONC & $-0.082^{*}$ & $-3.641^{* * *}$ \\
BIGN* INVES & $-0.034^{* *}$ & $-2.364 * * *$ \\
SIZE & $-0.052^{* * *}$ & -0.532 \\
LEV & $0.233^{*} * *$ & $2.662 * * *$ \\
& & \\
& $\mathrm{~N}=224$ & $\mathrm{~N}=224$ \\
& $\mathrm{R}^{2}=0.4471$ & Pseudo $\mathrm{R}^{2}=0.3368$ \\
& Adjusted $\mathrm{R}^{2}=0.4206$ & Log likelihood -67.97 \\
& Prob $>\mathrm{F}=0.0000$ & Prob $>$ Chi-2 0.0000
\end{tabular}

$*, * *$ and $* * *$ Correlations significant at the $10 \%, 5 \%$ and $1 \%$ level. $\mathrm{T}$ PERIOD $=$ Number of days between the financial year-end and the publication date $(\log ), \mathrm{AO}=$ "1" if auditor issued modified audit opinion ,"0" otherwise, $\mathrm{AC}=$ " 1 " if audit committee does exist within company ,"0" otherwise, $\mathrm{BSIZE}=$ Number of directors within the board, OUTDIR= Number of outside directors to total of directors within the board, CEO= " 1 " if there is duality function of the CEO, "0" otherwise, CONC= "1" if the proportions of shares held by the majority shareholder of the company $>20 \%$, "0" otherwise, INVES= Proportions of equity held by institutional investors, BIG N="1" if the auditor is a big $\mathrm{N}$ firm , "0" otherwise, SIZE= Log of firm's sales; LEV =Total liabilities to total assets
Concerning table 6 with the above cited, it reserves to determine the impact of the combination of the external auditor's characteristics and internal governance mechanisms of the above on the audit reporting quality. Testing this relationship, the external audit reputation (BIG N) has been introduced to be with the various internal governance mechanisms' indicators.

Worth highlighting the results presented on table 5 have been partially maintained on table 6 .

In fact, the latter shows that the presence of an Audit Committee, which appears to have no effect on the two measures of ARQ, turns out to have a negative and significant relationship with TPERIOD. This fact denotes that the audit committee plays a vital role in certificating the accounting process throng reducing laps necessary for external auditors to achieve their auditing activities (Shukeri, Islam (2012).Similarly, institutional ownership (INVE), which it's significantly negative effect on TPERIOD and AO, turns out to demonstrate on the two ARQ measures with respect to the new regression mode. It's worth noting, however, that the board size presence of outside directors in the board and combined Chairman and CEO functions sound to retain the same relationship trend but with significances that seem particularly different from the first regression. Besides, ownership concentration, within no significant effect on ARQ, is discovered to exhibit a significant relationship with TPERIOD. This result actually implies that whenever the ownership proves to be concentrated seems to pressure placed on external auditors to achieve within a remarkably short time interval, in a bid to reach greater timely information. Regarding control variables, firm size and debt retain the same significant relationships (bearing similar signs) with the various timeliness measurements.

Incorporation of external audit reputation as measured by BIG N has enabled to several the persistence of significant relationship with both TPERIOD and AO. This result indicates well that even the (BIG N) firms are able issuing ARQ, i.e. they take more time to complete the auditing mission (Ayemere and Elijah, 2015) for the sake of a high audit quality for the purpose of safeguarding their name and maintaining their reputation. This finding seems to be contradictory with most of the previous by elaborated research work highlighting that the Big $\mathrm{N}$ companies are capable of minimizing timely disclosure(Ahmed and Hossain, 2010; Afify, 2009; Mohamed-Nor and all ,2010; Modugu and all, 2012; Piot, 2008; Elfouzi and Zarai, 2008, Apadore and Mohd-Noor (2013), Lee and Jahng, 2008).However, However, this result proves to collaborate well with finding achieved by Shafie and all (2009) Abdelaziz and Moalla (2010) and Li and al (2008) how confirmed that the BIG N firms are more likely to issue audit modified audit opinion.

As for, the external auditor reputation variable interaction with the various internal governance mechanisms, it reveals the existence of three significant relationships along with three non-significant ones. In regard of internal governance mechanism's negative association with the external auditor's reputation, it shows the persistence of substitution relationships.

Indeed, the first combination (BIGN*BSIZE) shows a substitution effect between the board size and the external audit reputation on TPERIOD. This result sustains well the idea that large board size helps strengthen its control capacity and improve or extend its information sources (Pearce and Zahra, 1992) thanks to its diversified structure likely to provide better environmental links and exhibit greater expertise. As a matter of fact, broader efficiency helps well in facilitating the accounts' certification mission, allowing for substituting demand for reputable external auditor in a bid to minimize the timely disclosure.

Regarding the second (BIGN*CONC) combination shows substitution between ownership concentration and external audit reputation. This result seems well consistent with the agency theory stating that block holders are able to exert a restrictive control of managerial actions, which helps attenuate agency costs between shareholders and managers, render the emitted accounting information rather reliable and substitute demand for a 
reputable external audit to achieve the audit work within the legal deadline and to provide audit accuracy.

Concerning the third, combination (BIGN*INVES) demonstrates a substitution effect prevailing between institutional ownership and external audit reputation on audit reporting quality. It follows that with increased institutional investors; the latter would be rather inclined to actively monitor the financial "reporting" process reflecting weak a requirement for the external auditor executed tasks (Jensen et Meckling, 1976) to complete the audit check process and provide audit accuracy.

With regard to the non-significant associations between internal governance mechanisms and the external audit reputation, they suggest the absence of interaction between the presence of an Audit Committee, the outside director's proportion of the board, the accumulated Chairman and CEO functions along with demand for a reputable external audit deemed necessary to provide the audit reporting quality.

\section{Conclusion}

In an environment in which financial information should not only reflect the actually authentic firm image, but also promptly diffused the audit reporting quality would certainly constitute the major critical component and determinant factor of the financial information quality as well as a means where by the audit process efficiency and effectiveness could be assessed (Piot, 2008). In this context, the internal governance mechanisms effect audit reporting quality has been, firstly, investigated. In a second stage, these mechanisms' interaction with demand for reputable external auditor has been evaluated with respect to the timely disclosure audit accuracy, regarding Tunisian listed companies. The panel data regressions results have revealed that governance mechanisms significantly affecting timeliness subject of study, turn out to be : the Board of Directors (Board size and percentage of outside directors, combined Chairman and CEO functions) as well as ownership structure (capital concentration and institutional ownership), even though the significance signs prove to differ from one measure to another. Still, the attained results highlight to the prevalence of substitutability effects between the external audit reputation and ownership structure on the one hand, and between external audit reputation and Director's board size on the other. To note, demand for a reputable external audit could, by no means, not be a prerogative for both shareholders as well as for administrators, thanks to a substitution effect between control efficiency, as executed by some internal mechanisms and opting for a highly reputable auditor. Noteworthy, however, just like any research, the present study work suffers from certain limitations. Indeed, the investigated sample size has been reduced to 28 companies owing to unavailability of necessary data relevant to the period ranging between 2006 and 2013. In addition, there exist features of governance mechanisms (Directors' Board meeting frequency, Audit Committee size, audit committee independence, audit committee meeting frequency etc.), that may well influence audit reporting quality, but, which have not been dealt with as part of the present research, and could constitute subject of prospective work.

\section{References}

[1] Abdelsalam, O. H and Street, D. L (2007):"Corporate governance and the timeliness of corporate internet reporting by U.K. listed companies", Journal of International Accounting, Auditing \& Taxation, Vol. 16 Issue 2, 111. http://dx.doi.org/10.1016/j.intaccaudtax.2007.06.001.

[2] Abdullah, S. N., Mohamad-Yusof, N. Z., and Mohamad-Nor, M. N. (2010): "Financial restatement and corporate governance among Malaysian listed companies" Managerial Auditing Journal, Vol. 25(6), p526-552. http://dx.doi.org/10.1108/02686901011054854

[3] Ableaziz. A et Moalla. H (2010) :"les déterminants de l'opinion d'audit avec réserve : une analyse empirique en Tunisie", Crises etnouvelles problématiques de la Valeur, Nice : France (2010)"
[4] Afify H.A.E (2009):"Determinants of audit report lag Does implementing corporate governance have any impact? Empirical evidence from Egypt" Journal of Applied Accounting Research, Vol. 10 No. 1 , pp. 56-86. http://dx.doi.org/10.1108/09675420910963397.

[5] Ahmed. AAA and Hossain Md. S (2010) "Audit Report Lag: A Study of the Bangladeshi Listed Companies" ASA University Review, Vol. 4 No. 2.

[6] Al-Ajmi, J. (2008): "Audit and reporting delays: Evidence from an emerging market." Advances in Accounting, incorporating Advances in International Accounting".

[7] Al-ghanem, W and Hegazy, M. (2011) "An empirical analysis of audit delays and timeliness of corporate financial reporting in Kuwait" Eurasian Business Review, 1 (1) pp 73-90.

[8] Amari. M and Jarboui. A (2013): "Financial Reporting Delay and Investors Behavior: Evidence from Tunisia " International Journal Management Business Research. 3 (1), 57-67.

[9] Apadore. K and Mohd-Noor. N (2013): "Determinants of Audit Report Lag and Corporate Governance in Malaysia" International Journal of Business and Management, Vol. 8, No. 15; p1833-8119. http://dx.doi.org/10.5539/ijbm.v8n15p151.

[10] Ayadi W (2013):"Mécanismes de gouvernance et qualité de l'audit externe: Le cas français" La Revue Gestion et Organisation, Vol.5(2) p183-195. http://dx.doi.org/10.1016/j.rgo.2013.12.012.

[11] Ayemere. I.L and Elijah. A (2015):"Corporate Attributes and Audit Delay in Emerging Markets: Empirical Evidence from Nigeria ", International Journal of Business and Social Research, Vol 05, Issue 03.

[12]Azubike. J and aggreh. M (2014): "Corporate governance and audit delay in Nigerian quoted companies", European Journal of Accounting Auditing and Finance Research, Vol.2, No.10, pp.22-33.

[13]Baygi.S.J.H,Najrian.M, Vaghfi .S.H, Nahari.M and Kholousi. A (2012):"The Effects of Corporate Governance Mechanism on theAudit Report: Applying Fuzzy Regression" International Journal of Business and Management Tomorrow, Vol. 2 No. 7

[14]Bédard J and GendronY (2010): "Strengthening the Financial Reporting System: Can Audit Committees Deliver" International Journal of Auditing, p174-210. http://dx.doi.org/10.1111/j.1099 1123.2009.00413.x.

[15] Bonson-Ponte, E., Escobar-Rodriguez, T., \&Borrero-Dominguez, C. (2008):"Empirical analysis of delays in the signing of audit reports in Spain". International Journal of Auditing, 12(2), p129-140. http://dx.doi.org/10.1111/j.1099-1123.2008.00375.x.

[16] Chang.H , Chen.X , and Zhou.N (2013): " Determinants and Consequences of Audit Committee Effectiveness: Evidence from China"

[17]Che-Ahmad, A. and Abidin, S (2008): "Audit delay of listed companies: a case of Malaysia", International Business Research, 1, pp3239.

[18] Chen .G, Firth. M, GAO .D and M. Rui. O (2006):"Ownership structure, corporate governance, and fraud: Evidence from China" Journal of Corporate Finance, $12 \quad$ (2006), 424- 448 http://dx.doi.org/10.1016/j.jcorpfin.2005.09.002.

[19]Cohen S and Leventis .S (2013):" Effects of municipal, auditing and political factors on audit delay"AccountingForum, Vol 37, p40-53. http://dx.doi.org/10.1016/j.accfor.2012.04.002.

[20]Conover, C., Miller, R. and Szakmary, A. (2007) "The Timeliness of Accounting Disclosures in International Security Markets", International Review of Financial Analysis, 17 (5), pp. 849-869. http://dx.doi.org/10.1016/j.irfa.2007.07.002.

[21]Elfouzi.N.H AND Zarai .M.A (2008) " Impact du contenu informatif du rapport de l'auditeur sur le délai de sa signature : étude empirique menée dans le contexte tunisien"

[22]Ezat A, \& El-Masry, A, (2008): "The impact of corporate governance on the timeliness of corporate internet reporting by Egyptian listed companies" Managerial finance, Vol 34, pp 848 - 867. http://dx.doi.org/10.1108/03074350810915815.

[23] Farber D.B (2005): "Restoring Trust after Fraud: Does Corporate Governance Matter?" Accounting Review, Vol. 80, pp 539-561. http://dx.doi.org/10.2308/accr.2005.80.2.539.

[24]Farinha.J and Viana.L.F (2006):"Board Structure and Modified Audit Opinions: the Case of the Portuguese Stock Exchange"

[25]Francis, J. R., \&Yu, M. D. (2009) : "The effect of big four office size on audit quality"The Accounting Review, vol 84(5), pp1521-1552. http://dx.doi.org/10.2308/accr.2009.84.5.1521.

[26]Gul, F. A., \& Leung, S. (2004) "Board leadership, outside directors' expertise and voluntary corporate disclosures". Journal of Accounting and Public Policy, Vol 23, pp351-379. http://dx.doi.org/10.1016/j.jaccpubpol.2004.07.001.

[27] Habib A, and Bhuiyan B, (2011): "Audit firm industry specialization and the audit report lag", Journal of International Accounting, Auditing and Taxation, Vol 20, pp. 32-44. http://dx.doi.org/10.1016/j.intaccaudtax.2010.12.004. 
[28]Haniffa, R. M. and Cooke, T. E. (2002) "Culture, Corporate Governance and Disclosure in Malaysian Corporations" Abacus, Vol 38 (3) pp. 317-349. http://dx.doi.org/10.1111/1467-6281.00112.

[29]Jensen, M. C. (1993)"The modern industrial revolution, exit and the failure of internal control systems" Journal of Finance, 48 (3), pp 831-880. http://dx.doi.org/10.1111/j.1540-6261.1993.tb04022.x.

[30]Jensen, M. C., \&Meckling, W. (1976) "Theory of the firm: Managerial behavior", agency Journal.

[31]Johari, N., Saleh, N., Jaffer, R., and Hassan, M. (2008) "The Influence of Board Independence, Competency and Ownership on Earnings Management in Malaysia" International Journal of Economics and Management, vol.2, pp.281- 306.*

[32]LajmiA et Gana. M (2011)"Director's board characteristics and audit quality: evidence from Belgium". Journal of Modern Accounting and Auditing, Vol (7), pp 668- 679.

[33]Lee. H-Y and Jahng. G-J (2008) "Determinants of Audit Report Lag. Evidence from Korea - An Examination of Auditor-Related Factors" The Journal of Applied Business Research, Vol 24.

[34]Leventis, S., Weetman, P. and Caramanis C. (2005): "Determinants of Audit Report Lag: Some Evidence from the Athens Stock Exchange". International Journal of Auditing Vol. 9, pp 45- 58 http://dx.doi.org/10.1111/j.1099-1123.2005.00101.x.

[35]Li.C,Song.F.M, Wong.S (2008):" A Continuous Relation between Audit Firm Size and Audit Opinions: Evidence from China" International Journal of Auditing, Vol 12, pp111-127 http://dx.doi.org/10.1111/j.1099-1123.2008.00374.x.

[36] Marston, C. and Polei, A. (2004) "Corporate reporting on the internet by German companies" International Journal of Accounting Information Systems, Vol. 5, pp. 285-311 http://dx.doi.org/10.1016/j.accinf.2004.02.009.

[37]Mkadmi Je et Halioui K (2013): "Analyse de l'impact du conseil d'administration sur la performance des banques conventionnelles Malaisiennes" la Revue de Gestion et Organisation Volume 5, pp 16-26.

[38] Modugu. P.K, Eragbhe. E and Ikhatua .O. J (2012) " Determinants of Audit Delay in Nigerian Companies: Empirical Evidence", Research Journal of Finance and Accounting, Vol 3.

[39] Mohamad-Nor M.N, Shafie .R and Wan-Hussin. W.N (2010): "Corporate Governance and Audit Report Lag in Malysia" Asian Academy of Management Journal of Accounting and Finance, Vol. 6, No. 2, pp57-84

[40]Owusu-Ansah .S and Leventis .S (2006): "Timeliness of corporate annual financial reporting in Greece" European Accounting Review, Vol. $15, \quad$ No. $2, \quad$ pp273-287. http://dx.doi.org/10.1080/09638180500252078

[41] Pearce J.A. \& Zahra S.A., (1992), "Board composition from a strategic contingency perspective", Journal of Management Studies, Vol.29, pp.411-438. http://dx.doi.org/10.1111/j.1467-6486.1992.tb00672.x.

[42]Piot. C, (2008)"Les déterminants du délai de signature du rappor d'audit en France" Comptabilité - Contrôle - Audit, 2008/2 Tome 14, pp. 43-73.

[43]Pourali. M, Jozi.M, Rostami.K, Taherpour.G and Niazi.F (2013) "Investigation of Effective Factors in Audit Delay: Evidence from Tehran Stock Exchange (TSE) " Research Journal of Applied Sciences, Engineering and Technology, 5(2): pp405-410.

[44]Ruiz-barbadillo. E, Gomez-Aguilar .N, De Fentes-Barbera.C (2004) "Audit quality and the going-concern decision-making process: Spanish evidence " European Accounting Review, Vol. 13, No. 4, 597-620, 2004 http://dx.doi.org/10.1080/0963818042000216820.

[45]Shafie.R, Wan Hussin.W.R, Md. Yusof.M.F, and MdHussain, .M.H (2009):"Audit Firm Tenure and Auditor Reporting Quality: Evidence in Malaysia" International business Research, Vol 12

[46]Sharma, V. D (2004) "Board of directors' characteristics, institutional ownership, and fraud: evidence from Australia" Journal of Practice \&Theory, 23(2), pp 105-117 http://dx.doi.org/10.2308/aud.2004.23.2.105.

[47]Shukeri. S.N and Islam.Md. A (2012): "The Determinants of Audit Timeliness: Evidence From Malaysia", Journal of Applied Sciences Research, 8(7): pp3314-3322,

[48]Singh, M., Mathur, I. and Gleason, K.C. (2004): "Governance and performance implications of diversification strategies: evidence from large US firms", Financial Review, Vol. 39, pp. 489-526 http://dx.doi.org/10.1111/j.0732-8516.2004.00086.x.

[49]Tabachnick, B. G and Fidell, L. S. (2007)"Using multivariate statistics" (5th Ed.). Boston, MA: Allyn\&Bacon.

[50] Vuko .T and Cular. M (2014):"Finding determinants of audit delay by pooled OLS regression analysis", Croatian Operational Research Re view,pp 81-91.

[51]Wan-Hussin W.N and Bamahros H.M (2013): "Do investment in and the sourcing arrangement of the internal audit function affect audit delay?" Journal of Contemporary Accounting and Economics, pp19-32.
[52]Wan-Hussin, W. N. (2009): "The impact of family-firm structure and board composition on corporate transparency: Evidence based on segment disclosures in Malaysia" International Journal of Accounting, 44(4), pp313http://dx.doi.org/10.1016/j.intacc.2009.09.003.

[53]Wirtz. P (2004)" Meilleures pratiques de gouvernance, théorie de la firme et modèle de création de valeur : une appréciation critique des code de bonne conduite ", Cahier du FARGO.

[54]Xie, B., Davidson W. N and DaDalt, P. J. (2003) "Earnings management and corporate governance: The roles of the board and the audit committee", Journal of Corporate Finance, Vol. 9, June, pp. 295-314. http://dx.doi.org/10.1016/S0929-1199(02)00006-8.

[55]Zureigat Q.M (2011) "The Effect of Ownership Structure on Audit Quality: Evidence from Jordan" International Journal of Business and Social Science, Vol. 2 No. 10 